\title{
Effect of Sunlight on the Different Strata of Lake Water
}

\author{
Aneke Nwabueze Peter, Prof. Ademiluyi Joel Ojo
}

\begin{abstract}
Lake Water samples were collected from Nike Lake which is located in Enugu East Local Government Area of Enugu state, Nigeria. The lake water sample was poured into the experimental set-up. The samples were analysed for 13 physicochemical parameters and two microbial parameters according to standard procedures. Samples were tested at different time intervals for exposure to sunlight (day 1, day 7 and day 14). Turbidity, iron and dissolved oxygen exceeded the acceptable limits for surface water guidelines (NER, AUS-NZ and EQSSW). The results of the Water Quality Index (WQI) show an average value of 209.64 , indicating that the water in the lake is excessively polluted and unsuitable for drinking. Correlation analysis was carried out to investigate the strength of relationship between the physicochemical and microbiological parameters of lake water. Multiple regression analysis was done to investigate the effect of sunlight on the different strata of lake water. The results indicates that the days of exposure of lake water sample to sunlight and the depth of lake water column influences the concentrations of iron and total hardness. Principal component analysis (PCA) and cluster analysis (CA) were carried out to investigate the sources of contaminant of the lake water samples. The results shows that the lake water is influenced by impact from faecal contamination (principal component 1, 53.288\%), water hardness from rainwater which dissolves mineral matter and flows through the ground to the lake (principal component 2 , $18.101 \%$ ), impact from agricultural activity (principal component $3,13.066 \%$ ) and impact from domestic and industrial wastewater disposal (principal component 4 , $8.640 \%$ ).

Index Terms-Lake water, Stratification, Disinfection,
\end{abstract} Multiple Regression Analysis

\section{INTRODUCTION}

Thermal stratification is an important natural phenomenon in aquatic systems, which interferes significantly with their physical and chemical structure, creating complex gradients or simply leading to increased heterogeneity of the water column [28]. Latitude affects the stratification pattern and temperature of the upper mixed layer; therefore, stability changes are much more variable in the short term in the tropical than in the temperate lakes, especially if the winds are strong enough to cause vigorous motion in the upper water layer [7].

Lake thermal stratification occurs naturally due to the change in water's density with temperature [6]. Thermal stratification is as a result of solar radiation heating the lake's waters. In temperate lakes, stratification occurs annually as

Aneke Nwabueze Peter, Department of Civil Engineering, University of Nigeria, Nsukka, Nigeria

Prof. Ademiluyi Joel Ojo, Department of Civil Engineering, University of Nigeria, Nsukka, Nigeria the winter and summer months pass. Coupled with the effects of wind mixing, the water splits into three distinct layers in the summer. The warm upper layer is referred to as the epilimnion layer, the cool lower layer is referred to as the hypolimnion layer, and the shallow intermediate layer where the highest temperature drops occur is known as the metalimnion layer [16]. The amount of aquatic activity such as plant and animal growth is being determined by the thickness of the epilimnion layer [12].

Sunlight has been used to purify water for centuries. In India, around $2000 \mathrm{BC}$, water was filtered through charcoal and exposed to the sun [8]. The main objective of the study was to determine the effect of sunlight on various strata of lake water. The specific objectives are: to determine the physicochemical and microbial quality of the lake water samples and compare the results with established fisheries and recreational quality criteria standard, to evaluate the interaction between the water quality parameters (physicochemical and microbial) on the lake water quality and to determine the potential sources of contaminants on the lake water sample.

\section{MATERIALS AND METHODS}

\section{A. Experimental Set-up}

Fig. 1 shows the schematic diagram and pictures of the experimental set-up. The glass cylinder is made of borosilicate. The cylindrical glass was blown at the Scientific Equipment Development Institute, Enugu. The glass cylinder has a length of $0.92 \mathrm{~m}$ and a diameter of $700 \mathrm{~mm}$ to accommodate the lake water sample. The borosilicate glass has three glass tap with an opening for the collection of water sample. The glass taps are $300 \mathrm{~mm}$ apart. A wooden casing was constructed to accommodate the borosilicate glass. The wooden casing was constructed in such a way that laterite will be placed round the borosilicate glass except the space that was given to accommodate the glass taps for the collection of lake water sample. The experimental apparatus was set-up at the National Water Quality Reference Laboratory, Federal Ministry of Water Resources, Enugu, Nigeria.

Lake water samples from Nike Lake which is located at Enugu east local government area, Enugu state, Nigeria were collected using sterilized sampling devices. These samples were transported to the National Water Quality Reference Laboratory, Federal Ministry of Water Resources, Enugu, where the experimental set-up is located within 24 hours of sampling. The method of sampling and sampling preservation as stated in the Standard Methods for the examination of water and wastewater, which was published jointly by 


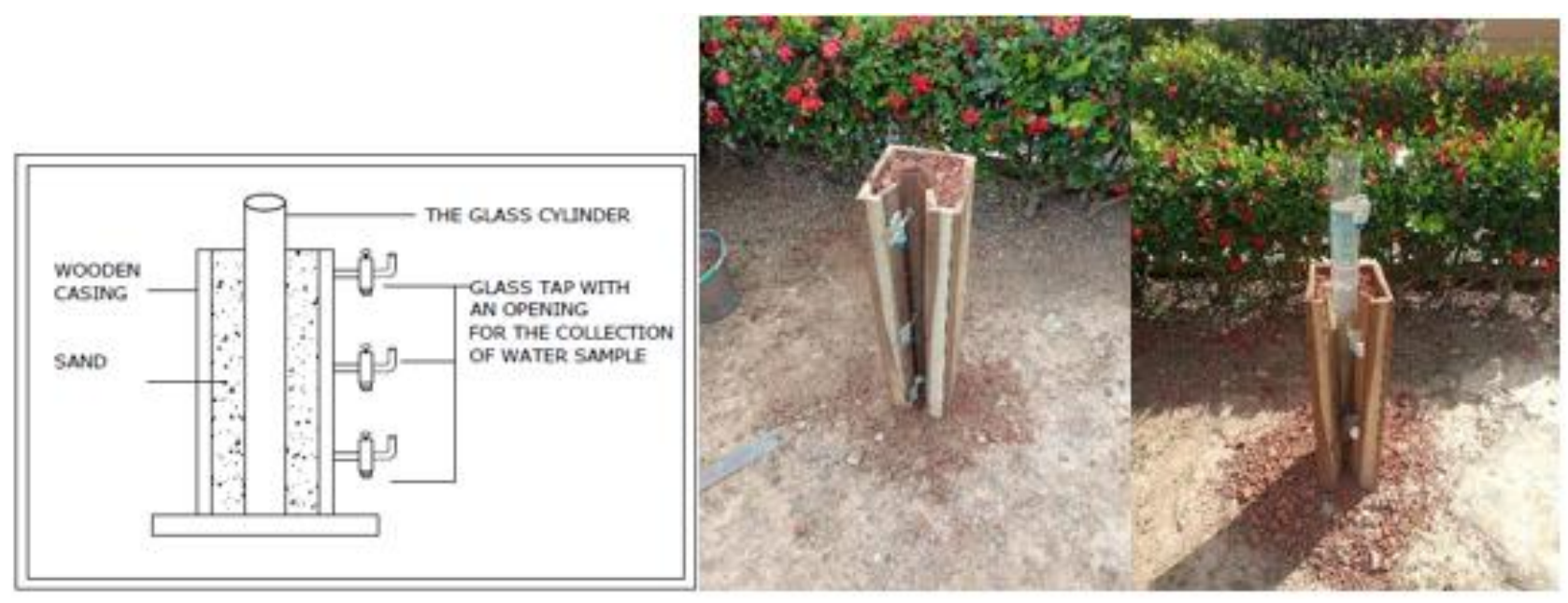

Fig. 1 The schematic diagram and pictures of the experimental set-up.

American Public Health Association (APHA), American Water Works Association (AWWA), and Water Environment Federation (WEF) in 2005 was followed strictly. A total of 15 physicochemical and microbiological parameters were tested for each sample.

The lake water sample was collected from the glass taps of the borosilicate glass. The three taps represents the top, the mid-point and the bottom layers of the Lake. In lake stratification, these layers are called the epilimnion (the top layer), the metalimnion (the mid-point) and the hypolimnion (the bottom layer). Lake water samples from the experimental set-up was collected and tested from the three different layers. Lake water sample was collected and transported to the laboratory on the $7^{\text {th }}$ October, 2019. The sample was tested and poured into the experimental set-up. The experimental set-up with the Lake water sample was exposed to sunlight. Samples were collected from the three different layers and tested after 24 hours, 7 days and 14 days. Temperature, $\mathrm{pH}$, turbidity, conductivity, total dissolved solids (TDS), phosphate, nitrate, iron, biochemical oxygen demand (BOD), chemical oxygen demand (COD), dissolved oxygen (DO), alkalinity, total hardness, total coliform, and Escherichia coli were measured according to standard procedures (APHA, 2005).

\section{B. Analysis of results}

A descriptive statistics of the physico-chemical and microbiological parameters was done and the test results were compared with three different surface water guidelines namely:

i. National Environmental (Surface and Groundwater Quality Control) Regulations, 2011 (Fisheries and Recreational Quality Criteria Standard).

ii. Australian and New Zealand (Guidelines for fresh and marine water quality) conservation council, 2000.

iii. China's environmental quality standard for surface water (EQSSW) (GB 3838- 2002).

The samples were tested for normality using the Shapiro-Wilks test for normality. After that, the parameters were correlated with each other using the Kendall's tau correlation to test if there is significant difference between any of the parameters. The water quality index (WQI) of the lake water was calculated to ascertain its suitability for domestic, industrial and agricultural purposes. The Weighted Arithmetic index method was used for the calculation of water quality index (WQI) of the surface water.

The effect of sunlight on the physico-chemical and microbiological parameters of the lake water column was determined using multiple regression analysis. Principal component analysis and cluster analysis was used to investigate the potential sources of contamination of the lake water samples.

\section{RESULTS AND DISCUSSION}

\section{A. Physicochemical and microbiological water quality in lake water samples}

The results of the physicochemical and microbiological analyses of lake water sample collected from Nike Lake and exposed to sunlight are presented in Table 1. These results were compared with two surface water guidelines, namely the National Environmental (Surface and Groundwater Quality Control) Regulations, 2011 (Fisheries and Recreational Quality Criteria Standard) and the Australian and New Zealand (Guidelines for fresh and marine water quality) conservation council, 2000.

The physicochemical parameter such as temperature, $\mathrm{pH}$, conductivity, total dissolved solids, phosphate, nitrate, biochemical oxygen demand (BOD), chemical oxygen demand (COD), alkalinity and total hardness were within the acceptable limit for fisheries and recreational water quality criteria standard according to NER (National Environmental Regulations). Turbidity, iron and dissolved oxygen exceeded the acceptable limits for fisheries and recreational water quality criteria standard. Sixteen water samples from two rivers (River Igbedi and River Nun) were tested by [2] and got dissolved oxygen values of $14.225 \pm 0.263$ and $10.200 \pm 0.283$ at the upstream and downstream of river Igbedi and dissolved oxygen values of $12.075 \pm 0.959$ and $13.275 \pm 0.096$ at the upstream and downstream of River Nun respectively. According to [25], turbidity values vary for two main reasons. One reason is physical such as heavy rains and fast-moving water which causes erosion. The other reason is biological due to algae growth and bacterial degradation of organisms in the

water column 
Table 1. Descriptive statistics of physicochemical and microbiological parameters monitored.

\begin{tabular}{|c|c|c|c|c|c|c|c|c|}
\hline Parameters & Method & $\mathbf{N}$ & Minimum & Maximum & Mean & $\begin{array}{l}\text { Standard } \\
\text { Deviation }\end{array}$ & $\begin{array}{l}\text { NER } \\
2011\end{array}$ & $\begin{array}{l}\text { AUS-NZ } \\
2000\end{array}$ \\
\hline $\begin{array}{c}\text { Temperature } \\
\left({ }^{\circ} \mathrm{C}\right)\end{array}$ & - & 10 & 24.80 & 28.80 & 26.27 & 1.217511 & - & - \\
\hline $\mathrm{pH} @ 25.0^{\circ} \mathrm{C}$ & $\begin{array}{c}\text { APHA } \\
4500 H^{*} \mathrm{~B}\end{array}$ & 10 & 5.39 & 8.74 & 7.093 & 1.072692 & $6.5-8.5$ & $6.5-8.5$ \\
\hline $\begin{array}{l}\text { Turbidity } \\
\text { (NTU) }\end{array}$ & $\begin{array}{l}\text { APHA } \\
2130 B\end{array}$ & 10 & 2.44 & 34.60 & 12.884 & 11.32235 & 5 & - \\
\hline $\begin{array}{c}\text { Conductivity } \\
(\mu \mathrm{S} / \mathrm{cm})\end{array}$ & $\begin{array}{l}\text { APHA } \\
2510 B\end{array}$ & 10 & 81.30 & 88.20 & 82.81 & 2.056129 & 1000 & - \\
\hline $\begin{array}{l}\text { Total Dissolved } \\
\text { Solids (mg/L) }\end{array}$ & $\begin{array}{l}\text { APHA } \\
2510 B \\
\end{array}$ & 10 & 48.80 & 53.00 & 49.86 & 1.241146 & 500 & - \\
\hline $\begin{array}{c}\text { Phosphate } \\
(\mathrm{mg} / \mathrm{L})\end{array}$ & $\begin{array}{l}\text { APHA } \\
4500-\mathrm{P} \\
\end{array}$ & 10 & 0.01 & 0.13 & 0.056 & 0.044522 & 3.5 & - \\
\hline Nitrate $(\mathrm{mg} / \mathrm{L})$ & $\begin{array}{c}\text { APHA } \\
4500-\mathrm{NO} 3 \mathrm{E}\end{array}$ & 10 & 1.40 & 6.00 & 2.74 & 1.613278 & 50 & 10 \\
\hline Iron $(\mathrm{mg} / \mathrm{L})$ & $\begin{array}{c}\text { APHA } \\
3500-\mathrm{FeB} \\
\end{array}$ & 10 & 0.33 & 1.30 & 0.657 & 0.309518 & 0.30 & 0.30 \\
\hline BOD (mg/L) & $\begin{array}{l}\text { APHA } \\
\text { 5210D }\end{array}$ & 10 & 0.60 & 2.90 & 2.04 & 0.655235 & 3 & - \\
\hline $\mathrm{COD}(\mathrm{mg} / \mathrm{L})$ & $\begin{array}{l}\text { APHA } \\
5220 \mathrm{D}\end{array}$ & 10 & 1.00 & 3.00 & 2.60 & 0.699206 & 30 & - \\
\hline $\begin{array}{c}\text { Dissolved } \\
\text { oxygen }(\mathrm{mg} / \mathrm{L})\end{array}$ & $\begin{array}{c}\text { APHA } \\
4500-\mathrm{OC}\end{array}$ & 10 & 5.70 & 8.80 & 8.01 & 0.864677 & 6.00 & - \\
\hline $\begin{array}{c}\text { Alkalinity } \\
(\mathrm{mg} / \mathrm{L})\end{array}$ & $\begin{array}{l}\text { APHA } \\
2320 \mathrm{~B}\end{array}$ & 10 & 4.00 & 20.00 & 13.60 & 4.427189 & - & - \\
\hline $\begin{array}{l}\text { Total Hardness } \\
(\mathrm{mg} \mathrm{CaCO} / \mathrm{L})\end{array}$ & $\begin{array}{l}\text { APHA } \\
2340 \mathrm{C}\end{array}$ & 10 & 10.00 & 28.00 & 18.20 & 6.356099 & 150 & 500 \\
\hline $\begin{array}{l}\text { Total Coliform } \\
\text { (cfu/100mL) }\end{array}$ & $\begin{array}{l}\text { APHA } \\
9222 B\end{array}$ & 10 & 0 & 600 & 180.00 & 252.9822 & 10 & - \\
\hline E. coli & $\begin{array}{l}\text { APHA } \\
9222 \mathrm{~B}\end{array}$ & 10 & 0 & 200 & 60.00 & 84.3274 & 0 & - \\
\hline
\end{tabular}

Also, [34] observed that the dissolved oxygen values of Kushiyara River in Bangladesh is $7.65 \pm 1.41$ during the rainy season and $6.33 \pm 0.85$ during the winter season. Since iron is one of the physicochemical parameters that exceeded the acceptable limit for the water quality standard in this study, this shows the excessive iron content makes the water turbid [35].

The microbiological analysis of the lake water was also reported in Table 1 . Out of a total of 10 lake water samples tested, $6(60 \%)$ had zero CFU/100mL while $4(40 \%)$ had values above zero CFU/100mL for Total coliform and Escherichia coli. The reduction in total coliform and Escherichia coli of Lake Water samples tested in day 7 and day 14 on exposure to sunlight at different strata was observed. Escherichia coli (E. coli) is the most common member of faecal coliform bacteria, indigenous to the intestinal tract of humans or other warm-blooded animal [9]. The presence of E. coli in Lake Water indicates the potential for the presence of pathogenic organisms [4]. Municipal wastewater discharges, septic leachate, agricultural or storm runoff, wildlife populations, or nonpoint sources of human and animal waste are the various sources of E. coli contamination in surface water [4]. According to the US Environmental Protection Agency (EPA), it is recommended that E. coli is a better indicator of faecal pollution than faecal coliform for purposes of evaluating ambient fresh water quality [36]. The US Public Health Service used an epidemiology study and observed detectable swimming associated health effects with total coliform levels of 2300 colony forming units (CFU)/100mL [10].

B. Correlation of the physicochemical and microbiological parameters of Lake Water samples

Correlation is a bivariate analysis that measures the strengths of association between two variables and the direction of the relationship ([13] and [38]). The physicochemical and microbiological parameters were tested for normality using Shapiro-Wilk's test for normality. Temperature, $\mathrm{pH}$, phosphate, iron, BOD, alkalinity and total hardness are normally distributed or parametric because their significant values (sig. values) are greater than 0.05 . Turbidity, conductivity, total dissolved solids, nitrate, COD, dissolved oxygen, total coliform and E. coli are not normally distributed or non-parametric because their significant values (sig. values) are less than 0.05. A non-parametric test called the Kendall's tau correlation was then used to correlate the physico-chemical and the microbiological parameters against each other. The Kendall's tau correlation coefficient is presented in Table 2. The correlation of the lake water parameters was done using SPSS (version 16.0) software. Temperature also affects biological activity and regulates the kind of organisms that can live in the Lake [25]. In this study, the Lake water temperature varied from $24.80^{\circ} \mathrm{C}$ to $28.80^{\circ} \mathrm{C}$ (Table

1). 
Table 2. A table showing the Kendall's tau correlation coefficients of all the parameters.

\begin{tabular}{|c|c|c|c|c|c|c|c|c|c|c|c|c|c|c|c|}
\hline \multicolumn{16}{|c|}{ Correlations } \\
\hline & $\begin{array}{l}\text { Tempera } \\
\text { ture }\left({ }^{\circ} \mathrm{C}\right)\end{array}$ & $\begin{array}{l}\mathrm{pH} @ \\
25.0 \text { 드 }\end{array}$ & $\begin{array}{c}\text { Turbidity } \\
\text { (NTU) }\end{array}$ & $\begin{array}{c}\text { Conductiv } \\
\text { ity } \\
(\mu \mathrm{S} / \mathrm{cm})\end{array}$ & $\begin{array}{c}\text { Total } \\
\text { Dissolved } \\
\text { Solids } \\
(\mathrm{mg} / \mathrm{L})\end{array}$ & $\begin{array}{l}\text { Phosphat } \\
\text { e(mg/L) }\end{array}$ & $\begin{array}{l}\text { Nitrate } \\
(\mathrm{mg} / \mathrm{L})\end{array}$ & $\begin{array}{c}\text { Iron } \\
(\mathrm{mg} / \mathrm{L}) \\
\end{array}$ & $\begin{array}{c}\text { Biochem } \\
\text { ical } \\
\text { Oxygen } \\
\text { Demand } \\
(\mathrm{mg} / \mathrm{L})\end{array}$ & $\begin{array}{c}\text { Chemical } \\
\text { Oxygen } \\
\text { Demand } \\
(\mathrm{mg} / \mathrm{L})\end{array}$ & $\begin{array}{c}\text { Dissolved } \\
\text { Oxygen } \\
(\mathrm{mg} / \mathrm{L})\end{array}$ & $\begin{array}{l}\text { Alkalinit } \\
\text { y (mg/L) }\end{array}$ & $\begin{array}{c}\text { Total } \\
\text { Hardness } \\
(\mathrm{mg} \\
\left.\mathrm{CaCO}_{\mathrm{z}} / \mathrm{L}\right)\end{array}$ & \begin{tabular}{|c|} 
Total \\
Coliform \\
$(\mathrm{cfu} / 100 \mathrm{~m}$ \\
$\mathrm{L})$
\end{tabular} & E. coli $(\mathrm{cfu} / 100 \mathrm{~mL})$ \\
\hline Temperature ( ${ }^{\circledR C}$ ) & 1.000 & & & & & & & & & & & & & & \\
\hline $\mathrm{pH} @ 25.0{ }^{\circ} \mathrm{C}$ & $.494^{*}$ & 1.000 & & & & & & & & & & & & & \\
\hline Turbidity (NTU) & -.045 & -.378 & 1.000 & & & & & & & & & & & & \\
\hline $\begin{array}{l}\text { Conductivity } \\
(\ddot{\mathrm{S}} / \mathrm{cm})\end{array}$ & .138 & .341 & -.386 & 1.000 & & & & & & & & & & & \\
\hline $\begin{array}{l}\text { Total Dissolved } \\
\text { Solids (mg/L) }\end{array}$ & .460 & .023 & -.068 & $.674^{* *}$ & 1.000 & & & & & & & & & & \\
\hline Phosphate(mg/L) & .094 & -.256 & $.675^{* *}$ & -.214 & .119 & 1.000 & & & & & & & & & \\
\hline Nitrate $(\mathrm{mg} / \mathrm{L})$ & $.659^{* * *}$ & .135 & .135 & .184 & $.506^{*}$ & .047 & 1.000 & & & & & & & & \\
\hline Iron $(\mathrm{mg} / \mathrm{L})$ & -.045 & -.378 & $.733^{* *}$ & -.250 & .068 & $.861^{* * *}$ & -.045 & 1.000 & & & & & & & \\
\hline $\begin{array}{l}\text { Biochemical } \\
\text { Oxygen Demand } \\
(\mathrm{mg} / \mathrm{L})\end{array}$ & .159 & $.674^{* * *}$ & -.449 & .230 & -.092 & -.141 & -.114 & -.270 & 1.000 & & & & & & \\
\hline $\begin{array}{l}\text { Chemical Oxygen } \\
\text { Demand (mg/L) } \\
\end{array}$ & -.031 & .528 & -.528 & .382 & -.064 & -.293 & -.094 & -.466 & $.723^{* *}$ & 1.000 & & & & & \\
\hline $\begin{array}{l}\text { Dissolved } \\
\text { Oxygen }(\mathrm{mg} / \mathrm{L})\end{array}$ & -.414 & .068 & -.477 & -.070 & -.395 & $-.619^{*}$ & -.368 & $-.568^{*}$ & .046 & .223 & 1.000 & & & & \\
\hline Alkalinity $(\mathrm{mg} / \mathrm{L})$ & .341 & $.719^{* * *}$ & -.180 & .276 & -.046 & -.141 & .159 & -.180 & $.568^{*}$ & .440 & -.230 & 1.000 & & & \\
\hline $\begin{array}{l}\text { Total Hardness } \\
(\mathrm{mg} \mathrm{CoCO} / \mathrm{L})\end{array}$ & -.046 & .205 & .341 & .023 & -.163 & .071 & .046 & .068 & -.046 & .032 & -.209 & .368 & 1.000 & & \\
\hline $\begin{array}{l}\text { Total Coliform } \\
\text { (cfu/100mL) }\end{array}$ & .199 & -.282 & $.732^{* *}$ & -.144 & .202 & $.797^{* * *}$ & .256 & $.789^{* *}$ & -.370 & -.512 & $-.692^{*}$ & -.085 & .317 & 1.000 & \\
\hline $\begin{array}{l}\text { E. coli } \\
\text { (cfu/100mL }\end{array}$ & .199 & -.282 & $.732^{* *}$ & -.144 & .202 & $.797^{* * *}$ & .256 & $.789^{* * *}$ & -.370 & -.512 & $-.692^{*}$ & -.085 & .317 & $1.000^{* *}$ & 1.000 \\
\hline
\end{tabular}

**. Correlation is significant at the 0.01 level (2-tailed)

*. Correlation is significant at the 0.05 level (2-tailed). 
From Table 2, the correlation between temperature vs $\mathrm{pH}$ and temperature vs nitrate gave a correlation coefficient value of $r=0.494$ and $r=0.695$ respectively. The correlation between temperature vs $\mathrm{pH}$ is significant at $\mathrm{p}<0.05$ while the correlation between temperature vs nitrate is significant at $\mathrm{p}<$ 0.01 . Temperature did not show a significant correlation with dissolved oxygen but negative correlation with dissolved oxygen $(r=-0.414)$. This shows that when water temperature increases, the metabolic rate of microorganisms also increases and the amount of dissolved oxygen in water decreases [34]. The significant positive correlation between temperature and $\mathrm{pH}$, nitrate indicates their rise with temperature.

The $\mathrm{pH}$ of a solution is a measure of the concentration of hydrogen ions $\left(\mathrm{H}^{+}\right)$and it represents the negative logarithm of hydrogen ions concentration. The hydrogen ion concentration $(\mathrm{pH})$ is an important factor that determines the suitability of water for various purposes, including toxicity to animals and plants [19]. In this study, the $\mathrm{pH}$ value of the Lake water varied from 5.39 to 8.74 and an average of $7.093 \pm 1.072692$. About $40 \%$ of the tested Lake water samples had $\mathrm{pH}$ values within the NER (National Environmental Regulations) limit for surface and groundwater quality control. The $\mathrm{pH}$ showed positive and strong correlation with BOD (Biochemical Oxygen Demand) and alkalinity. The correlation between $\mathrm{pH}$ vs BOD and $\mathrm{pH}$ vs alkalinity gave a value of $r=0.674$ and $r=0.719$ respectively. All of them were significant at $p<0.01$. This signifies that an increase in the $\mathrm{pH}$ of the Lake water sample will cause an increase in BOD and alkalinity. One of the reasons of $\mathrm{pH}$ change in water is the photosynthesis [25]. This process absorbs carbon dioxide from the water and uses the energy of the sun to convert it to simple organic carbon compounds and to produce oxygen (equation 1). Carbon dioxide in the solution has an acidifying effect as it reacts with water and forms carbonic acid $\left(\mathrm{H}_{2} \mathrm{CO}_{3}\right)$. As long as it is removed by plants and algae, the water will become more alkaline and the $\mathrm{pH}$ will increase [25].

$$
\begin{aligned}
& 106 \mathrm{CO}_{2}+16 \mathrm{NH}_{4}^{+}+\mathrm{HPO}_{4}^{2-}+65 \mathrm{H}_{2} \mathrm{O} \rightarrow \\
& \mathrm{C}_{106} \mathrm{H}_{181} \mathrm{O}_{45} \mathrm{~N}_{16 \mathrm{P}+118 \mathrm{O}_{2}+14^{\mathrm{H}^{+}}}
\end{aligned}
$$

The $\mathrm{pH}$ also showed negative and weak correlation with turbidity and total coliform. The correlation of $\mathrm{pH}$ vs turbidity gave $\mathrm{r}=-0.378$ and that of $\mathrm{pH}$ vs total coliform gave $\mathrm{r}=$ -0.282 but they were insignificant.

Turbidity indicates the amount of suspended solids in the water, either mineral (such as soil particles) or organic (like algae). The turbidity analysis is a measure of the amount of light scattered in water and the more suspended particles cause greater scattering and thus high turbidity value [25]. In this study, turbidity was above the limit for surface water and groundwater control guideline.

Turbidity showed strong and positive correlation with phosphate, iron, total coliform and E. coli with correlations of $0.675,0.733,0.732$ and 0.732 respectively. All of them were significant at $\mathrm{p}<0.01$. Also, the turbidity value varies due to algae growth and bacterial degradation of organics in the water column [29].
Phosphorous is essential for the growth of organisms and generally limits the primary productivity in water. In this study, the values of phosphate varied from 0.01 to $0.13 \mathrm{mg} / \mathrm{L}$ and an average of $0.056 \pm 0.044522 \mathrm{mg} / \mathrm{L}$ (Table 1).

Phosphate showed strong and positive correlation with iron, total coliform and E. coli with a correlation coefficient of $r=$ $0.861, r=0.797$ and $r=0.797$ respectively. All of them were significant at $\mathrm{p}<0.01$.

Biochemical Oxygen Demand value indicates organic pollution in the aquatic systems, which adversely affect the river quality and biodiversity [33]. In this study, the values of BOD varied from 0.60 to $2.90 \mathrm{mg} / \mathrm{L}$ with an average of $2.04 \pm 0.655235 \mathrm{mg} / \mathrm{L}$ (Table 1 ).

BOD showed strong and positive correlation with Chemical Oxygen Demand (COD) and alkalinity with a correlation coefficient of $(r=0.723, p<0.01)$ and $(r=0.568, p<0.05)$ respectively. BOD showed a negative correlation with total hardness with a correlation coefficient of $r=-0.046$ and it is not significant.

According to [18], dissolved oxygen can be defined as the concentration of oxygen molecule in water which depends on temperature of the water and biochemical oxygen demand of the system. As a very important water quality parameter, the recommended minimal value of dissolved oxygen for domestic use and to maintain good fish population is $5 \mathrm{mg} / \mathrm{L}$ [14]. The amount of diffusing oxygen in the aquatic environment is dependent very much on temperature [24]. Dissolved oxygen showed negative and strong correlation with phosphate and iron with correlation coefficients of $(\mathrm{r}=$ $-0.619, \mathrm{p}<0.05)$ and $(\mathrm{r}=-0.568, \mathrm{p}<0.05)$ respectively. Dissolved oxygen also showed negative and strong correlation with total coliform and Escherichia coli with correlation coefficients of $(\mathrm{r}=-0.692, \mathrm{p}<0.05)$ and $(\mathrm{r}=$ $-0.692, \mathrm{p}<0.05)$ respectively. This shows that the activities of microorganisms cause a reduction in the amount of dissolved oxygen in the water.

Alkalinity in a solution means the solution is capable of buffering acidic solutions with higher concentrations of hydrogen ions. Alkalinity in water comes from a high concentration of carbon-based mineral molecules suspended in the solution [29]. Guideline values were not provided for alkalinity by National Environmental Regulations (NER). This is because they believe that alkalinity are not found in concentrations harmful to the humans in surface water and groundwater. Alkalinity showed positive correlation with total hardness and negative correlation with E. coli with correlation coefficients of $r=0.368$ and $r=-0.085$ respectively.

Total Hardness is a very important property of water from its domestic application point of view. Total hardness is made up of calcium and magnesium concentrations. Total hardness had a range of 10 to $28 \mathrm{mg} / \mathrm{L}$ with a mean value of $18.20 \pm 6.36 \mathrm{mg} / \mathrm{L}$ which is well below the NER guideline for surface and groundwater. Total hardness showed positive correlation with total coliform $(\mathrm{r}=0.317)$ and $\mathrm{E}$. coli $(\mathrm{r}=$ $0.317)$ respectively.

\section{$B$. Water quality index}

The water quality index was calculated using three different surface water quality guidelines. They are the National Environmental Regulations (NER) guidelines for surface and groundwater quality control, the Australian and New Zealand 
(Guidelines for fresh and marine water quality) conservation council and the China's environmental quality standard for surface water (GB 3838- 2002). The weighted arithmetic water quality index method was used.

The water quality index value for the NER guidelines for fisheries and recreational quality criteria standard was gotten as 216.76, that of the Australian and New Zealand conservation council was gotten as 206.02, while that of the China's environmental quality standard for surface water (GB 3838- 2002) was gotten as 206.14. The results of the Water Quality Index (WQI) show an average value of 209.64, this shows that the status of the Lake is excessively polluted and unsuitable for drinking.

\section{C.Multiple linear regression analysis of Lake Water parameters}

According to [20], multiple linear regression is a statistical method for understanding the relationship between an outcome variable (dependent variable) and several independent variables that best represent the relationship in a population. The method is used for predictive and explanatory purposes, both experimental and non-experimental. Multiple linear regression was applied on surface water quality data by [22] with the aim of identifying their contribution toward water quality variation. 150 bore well water samples were analysed by [26]. They conducted a multiple regression analysis and observed that $99.9 \%$ of the variability in electrical conductivity could be attributed to the combined effect of $\mathrm{Cl}^{-}, \mathrm{HCO}_{3}^{-}, \mathrm{NO}_{3}^{-}$and $\mathrm{SO}_{4}^{2-}$. They also noted that the multiple regression model can predict ground water quality parameters with $5 \%$ level of significance [26].

Multiple linear regression analysis was performed by using the SPSS (version 16.0) software. It was used in predicting the effect of sunlight on the physicochemical and microbiological parameters of lake water. Shapiro-Wilk's test for normality was conducted on the lake water parameters. Temperature, $\mathrm{pH}$, phosphate, iron, biochemical oxygen demand (BOD), alkalinity and total hardness were normally distributed or parametric. Multiple linear regression was performed on the parameters that were normally distributed. Table 3 shows the contribution of two independent variables (days of exposure to sunlight and the depth of lake water column) on predicting its effect on the dependent variables (lake water parameters).

Table 3. Individual contribution of various independent variables to predict its effect on lake water sample.

\begin{tabular}{|c|c|c|c|c|}
\hline \multirow{3}{*}{ Dependent variable $\left(R^{2}\right)$} & \multicolumn{4}{|c|}{ Independent variables } \\
\hline & \multicolumn{2}{|c|}{$\begin{array}{l}\text { Days of exposure of lake water sample to } \\
\text { sunlight }\end{array}$} & \multicolumn{2}{|c|}{ Depth of lake water column } \\
\hline & p-value & t-stat & p-value & t-stat \\
\hline Temperature $(0.110)$ & 0.998 & -0.002 & 0.397 & -0.903 \\
\hline $\mathrm{pH}(0.535)$ & 0.042 & 2.490 & 0.504 & 0.704 \\
\hline Phosphate (0.789) & 0.004 & -4.225 & 0.119 & -1.775 \\
\hline Iron $(0.839)$ & 0.003 & -4.538 & 0.029 & -2.742 \\
\hline BOD (0.482) & 0.077 & 2.070 & 0.376 & 0.945 \\
\hline Alkalinity (0.420) & 0.374 & 0.949 & 0.124 & 1.749 \\
\hline Total hardness $(0.718)$ & 0.010 & -3.473 & 0.016 & 3.171 \\
\hline
\end{tabular}

From Table 3 , the multiple $R^{2}$ value $(0.110)$ indicates that $11.0 \%$ of the variability in water temperature could be attributed to the combined effect of the days of the exposure of lake water sample to sunlight and the depth of lake water column. With p-values of 0.998 and 0.397 for the days of exposure of lake water sample to sunlight and the depth of lake water column at $\mathrm{t}$-stat of -0.002 and -0.903 respectively. This signifies that the independent variables (days of exposure of lake water sample to sunlight and the depth of lake water column) is not significant and has no effect on the lake water temperature.

From Table 3, a multiple $R^{2}$ value of 0.535 indicates that $53.5 \%$ of the variability in $\mathrm{pH}$ could be attributed to the combined effect of the days of exposure of lake water sample to sunlight and the depth of lake water column. For the days of exposure of lake water sample to sunlight, the p-value of 0.042 indicates that the independent variable (days of exposure of lake water sample to sunlight) is significant at t-stat value of 2.490. The independent variable (depth of lake water column) has a p-value of 0.504 and it indicates that it is not significant at a t-stat value of 0.704 . The p-values of the independent variables indicates that the days of exposure of lake water samples to sunlight has an effect on the $\mathrm{pH}$ of the lake water sample while the depth of the lake water column has no effect on the $\mathrm{pH}$ of lake water sample.

From Table 3, a multiple $R^{2}$ value of 0.789 indicates that $78.9 \%$ of the variability in phosphate could be attributed to the combined effect of the independent variables. The days of exposure of lake water sample to sunlight has a p-value of 0.004 , which signifies that the independent variable is significant at $t$-stat value of -4.225 . Also, the depth of lake water column has a p-value of 0.119 which indicates that the independent variable (depth of lake water column) is not significant at t-stat value of -1.775 . From the $\mathrm{p}$-values, the days of exposure of lake water sample to sunlight has an effect on phosphate but the depth of water column has no effect on phosphate of the lake water sample.

Multiple $R^{2}$ value of 0.839 indicates that $83.9 \%$ of the variability in iron could be attributed to the combined effect 
of the independent variables (days of exposure of lake water sample to sunlight and the depth of lake water column) (Table 3 ). The independent variables (days of exposure of lake water sample to sunlight and the depth of lake water column) gave p-values of 0.003 and 0.029 at t-stat values of -4.538 and -2.742 respectively. This indicates that the independent variables are significant and that they have an effect on iron of lake water sample. The multiple regression equation was given as:

Iron $=1.139-0.038$ [days of exposure to sunlight $]-0.429$ [depth of lake water column]

(2)

From Table 3, with p-values of 0.077 and 0.376 , this indicates that the days of exposure of lake water sample to sunlight and the depth of lake water column are not significant at t-stat values of 2.070 and 0.945 respectively. Also, from Table 3, a multiple $R^{2}$ value of 0.482 indicates that $48.2 \%$ of the variability in BOD could be attributed to the combined effect of the independent variables (days of exposure of lake water sample to sunlight and the depth of lake water column). From the p-values, the independent variables have no effect on the BOD of lake water sample.

The p-values of the independent variables (0.374 and 0.124 ) indicates that the independent variables (days of exposure of lake water sample to sunlight and the depth of lake water column) are not significant at t-stat values of 0.949 and 1.749 respectively (Table 3). A multiple $R^{2}$ value of 0.420 indicates that $42.0 \%$ of the variability in alkalinity could be attributed to the combined effect of the days of exposure of lake water sample to sunlight and the depth of lake water column. From the p-values, the days of exposure of lake water sample to sunlight and the depth of lake water column has no effect on alkalinity of lake water sample.

From Table 3, a multiple $R^{2}$ value of 0.718 indicates that $71.8 \%$ of the variability of total hardness could be attributed to the combined effect of the days of exposure of lake water sample to sunlight and the depth of lake water column. The p-values of the independent variables (0.010 and 0.016) indicates that they are significant at t-stat values of -3.473 and 3.171 respectively. From the p-values, the independent variables (the days of exposure of lake water sample to sunlight and the depth of lake water column) has an effect on the total hardness of lake water sample. The multiple regression equation was given as:

Total hardness $=16.129-0.789$ [days of exposure to sunlight] +13.477 [depth of lake water column]

\section{(3)}

D.Principal component analysis of the physicochemical and microbiological parameters of Lake Water samples

According to [30], principal component analysis (PCA) is a multivariate statistical approach designed to turn the complexity of input variables with a large amount of information into new non-correlated variable called principal components, which are linear combinations of the original variables. And it is supposed to provide a clearer understanding of the original variables. Principal component analysis offers details on the essential parameters with minimal data loss [32]. Principal component analysis was performed using SPSS (version 16.0) software.
Firstly, the standardized principal component analysis was used to analyze the data. This method was useful because the parameters have a wide variety of units and magnitudes. In addition, the standardization process reduces the effect of the various measurement units and makes the data dimensionless [37]. This approach consists first of standardizing the data by turning the covariance matrix into a correlation matrix before the principal component analysis is carried out [23]. Various standardization approaches exist, but in this study, standardization was accomplished by subtracting the group mean from each variable and dividing it by the group standard deviation to allow all the data to have zero mean and a unit variance. Kaiser-Meyer-Olkin (KMO) measure of sampling adequacy and Bartlett's test of sphericity were used to check the suitability of the data for principal component analysis [30]. The data is not suitable for principal component analysis.

From Table 4, the first principal component (PC1) had high positive loading on temperature, turbidity, phosphate, nitrate, iron, total coliform and E. coli. The first principal component indicates sewage discharge and faecal contamination of the lake water. Coliform bacteria are excreted in large quantities in human faeces and in other warm-blooded animals [17]. As a result, water polluted with faecal matter is identified as potentially harmful due to indicator organisms co-existing with E. coli that causes cholera. Examples of diseases caused by drinking or bathing in faecal polluted water include diarrhea, cholera, dysentery and skin, eye, ear, nose and throat infections [39].

The second principal component (PC2) had high positive loading on $\mathrm{pH}$, conductivity, total dissolved solids, alkalinity and total hardness (Table 4). Therefore, the second principal component represent water hardness. Sources of water hardness could be the result of rainwater that dissolves mineral matter as it flows through the ground on its way to rivers, lakes and springs [1]. Limestone (which introduces calcium to the water) and dolomite (which introduces magnesium) are the most common sources of water hardness [28]. According to [28], water hardness on the basis of dissolved concentrations of calcium and magnesium can be categorized as soft (0-60 mg/L), moderate (61-120 mg/L), hard (121-180 mg/L) and very hard (over $180 \mathrm{mg} / \mathrm{L})$. From Table 1, the lake water samples can be categorized as very soft water.

The third principal component (PC3) has high positive loading on temperature and nitrate and a negative loading on dissolved oxygen (Table 4). PC3 represents the nutrient factor. This indicates that there was a high degree of agricultural activity in the lake environment and that this has resulted in nutrient pollution from fertilizers [17]. Large amounts of dissolved organic matter in lake water consumes large amount of oxygen which results in decrease in the amount of available dissolved oxygen [21]. The nutrient component reflects effects from non-point sources such as agricultural run-off and atmospheric deposition [21].

The fourth principal component (PC4) has high positive loading on $\mathrm{pH}$ and weak positive loading on temperature, phosphate, BOD and alkalinity (Table 4). PC4 may indicate organic pollution from domestic and industrial wastewater disposed to the lake. Elevated concentrations of dissolved organic matter and biological organic matter arise from waste disposal practices or runoff of solids [40]. Influences from 
municipal and industrial point-source wastes, non-point agricultural sources, agricultural sources, livestock and/or domestic sources can be identified with organic and nutrient variables [31].

E.Cluster analysis of the physicochemical and microbiological parameters of Lake Water samples.

Cluster analysis is a method used to identify related and close objects within a data set and to group these objects into clusters based on their characteristics ([5] and [15]).

Table 4. Loadings (Coefficients) of the first four principal components.

Component Matrix ${ }^{a}$

\begin{tabular}{|c|c|c|c|c|}
\hline & \multicolumn{4}{|c|}{ Component } \\
\hline & 1 & 2 & 3 & 4 \\
\hline TEMPERATURE & .627 & .180 & .659 & .351 \\
\hline $\mathrm{PH}$ & -.637 & .455 & .332 & .482 \\
\hline TURBIDITY & .941 & .214 & -.211 & .054 \\
\hline CONDUCTIVITY & -.042 & .822 & .255 & -.490 \\
\hline TDS & .322 & .698 & .399 & -.482 \\
\hline PHOSPHATE & .875 & .293 & -.219 & .201 \\
\hline NITRATE & .560 & -.082 & .695 & -.024 \\
\hline IRON & .945 & .130 & -.153 & .170 \\
\hline BOD & -.826 & .344 & .040 & .385 \\
\hline COD & -.819 & .386 & .027 & .038 \\
\hline DISSOLVED OXYGEN & -.895 & .078 & -.336 & -.194 \\
\hline ALKALINITY & -.648 & .554 & -.092 & .390 \\
\hline TOTAL HARDNESS & .091 & .686 & -.600 & -.084 \\
\hline TOTAL COLIFORM & .908 & .230 & -.233 & .156 \\
\hline E-COLI & .908 & .230 & -.233 & .156 \\
\hline
\end{tabular}

Extraction Method: Principal Component Analysis.

a. 4 components extracted.

Rescaled Distance Cluster Combine

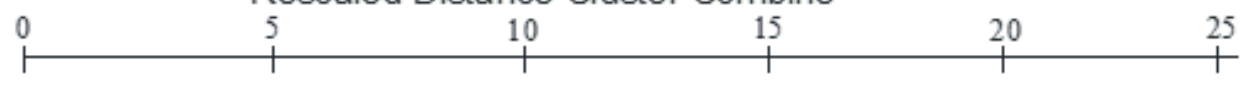

Total Coliform
E. Coli
Phosphate
Iron
Turbidity
Temperature
Nitrate
Conductivity
Total Dissolved Solids
Total Hardness
Biochemical Oxygen Demand
Chemical Oxy gen Demand
pH
Alkalinity
Dissolved Oxygen

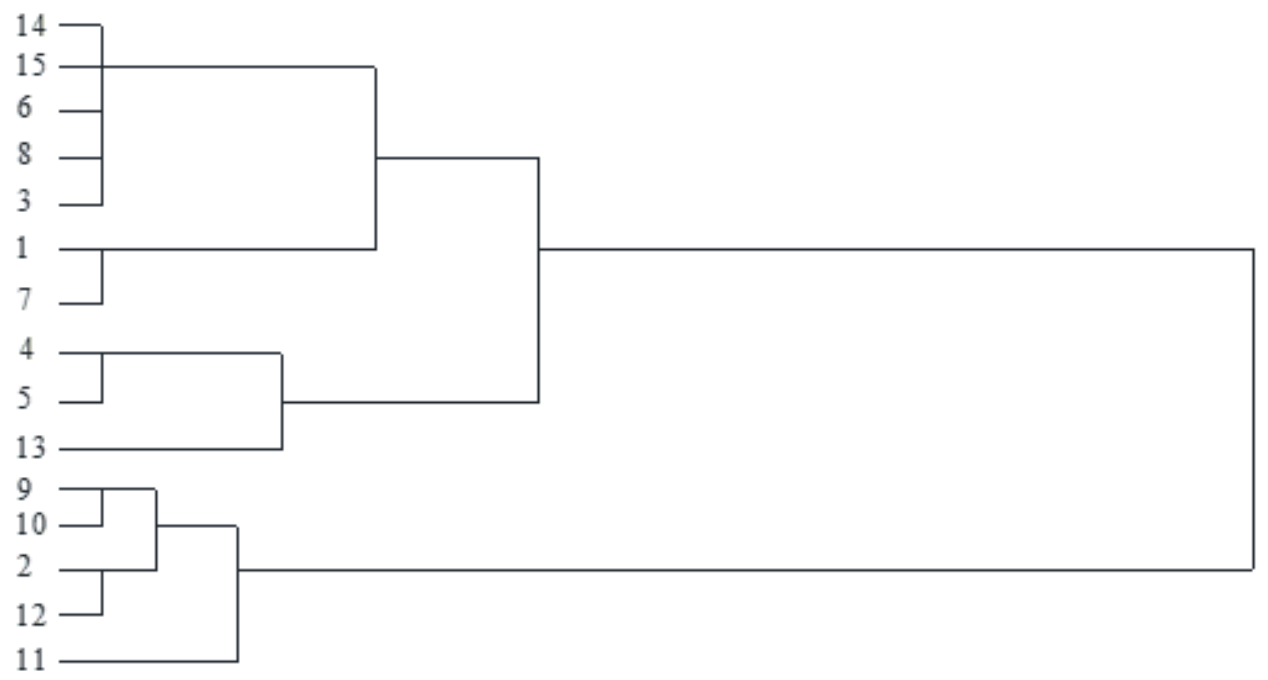

Fig. 2 Dendrogram based on hierarchical method (Ward's method) for the physico-chemical and microbiological parameters of lake water. 
Hierarchical clustering is the most common method in which clusters are arranged successively, beginning with the most similar pair of objects and generating clusters step by step, which is generally represented by a dendrogram [11]. The data sets produced in this study were treated by a cluster method known as Ward's method of linkage using squared Euclidean distance as its measure of similarity.

The dendrogram of the lake water parameters obtained by Ward's method is shown in Fig. 2. The outcome of the principal component analysis was fairly replicated by the cluster analysis. Cluster analysis was performed using SPSS (version 16.0) software.

Fig. 2 shows a cluster groupings of the physico-chemical and microbiological parameters of lake water. Group A consists of total coliform, E. coli, phosphate, iron and turbidity and thus corresponds with PC1. Group B is made up of temperature and nitrate which corresponds with PC3. Group C comprises of conductivity, total dissolved solids and total hardness which corresponds with PC2. Group D consists of BOD, $\mathrm{pH}$ and alkalinity which corresponds with PC4. Table 4.8 shows how the principal component analysis (PCA) results correspond with cluster analysis (CA).

\section{CONCLUSION}

The physicochemical and microbiological properties of Nike Lake water sample on exposure to sunlight were well within the National Environmental Regulation (NER) guideline for surface and groundwater except for turbidity, iron, dissolved oxygen, total coliform and Escherichia coli. The results of water quality index (WQI) calculations shows that the lake water is excessively polluted and unsuitable for drinking.

The multiple linear regression analysis shows that the days of exposure of lake water sample and the depth of lake water column influences the concentration of iron and total hardness from the lake water sample. The multiple linear regression model gives good accuracy for forecasting the concentrations of iron and total hardness where $R^{2}$ values are 0.839 and 0.718 respectively (Table 3 ). The model indicates that $83.9 \%$ and $71.8 \%$ variability of the concentrations of iron and total hardness is attributed by the two independent variables used in the model. The principal component analysis and cluster analysis shows that the lake water was contaminated as a result of agricultural or storm runoff, wildlife populations, and non-point sources of human and animal wastes, water hardness from rainwater as it dissolves mineral matter as it flows through the ground to the lake and industrial wastes disposed on the lake. Correlation of lake water parameters shows that temperature affects biological activity and regulates the kind of organisms that can live in the lake. Also, turbidity value indicates the algae growth and bacterial degradation of organisms in the water column. E. coli and Total coliform indicates the presence of faecal contamination of water and it can happen when faeces of animals or humans is deposited on the lake water.

Sunlight has a disinfecting effect and it helps in improving water quality. From this study, it is recommended that intake works can be constructed to a required depth. The intake works should be constructed at the epilimnion layer of Lakes. Sunlight has a maximum disinfecting effect at the epilimnion layer (top layer).

\section{ACKNOWLEDGMENT}

We wish to acknowledge the team from Science Equipment Development Institute, Enugu, Nigeria for helping us to blow the borosilicate glass used in conducting the experiment.

\section{REFERENCES}

[1] Abeliotis, Konstadinos, Cevza Candan, Caroline Amberg, Ada Ferri, Miguel Osset, Jeremy Owens, and Rainer Stamminger. "Impact of water hardness on consumers' perception of laundry washing result in five European countries." International Journal of Consumer Studies 39, no. 1 (2015): 60-66.

[2] Agedah, Ebisomu C., Ebinyo Rebecca Ineyougha, Sylvester Chibueze Izah, and Langley Ayibawanaimi Orutugu. "Enumeration of total heterotrophic bacteria and some physico-chemical characteristics of surface water used for drinking sources in Wilberforce Island, Nigeria." Journal of Environmental Treatment Techniques 3, no. 1 (2015): 28-34.

[3] American Public Health Association, American Water Works Association, Water Pollution Control Federation, and Water Environment Federation. Standard methods for the examination of water and wastewater. Vol. 2. American Public Health Association, 2005.

[4] An, Youn-Joo, Donald H. Kampbell, and G. Peter Breidenbach. "Escherichia coli and total coliforms in water and sediments at lake marinas." Environmental Pollution 120, no. 3 (2002): 771-778.

[5] Andreopoulos, Bill. "Clustering categorical data." Wiley StatsRef: Statistics Reference Online (2014): 1-12.

[6] Brönmark, C., and L. A. Hansson. "The Biology of Lakes and Ponds, -Oxford University Press." (2005)

[7] Cantin, Ariane, Beatrix E. Beisner, John M. Gunn, Yves T. Prairie, and Jennifer G. Winter. "Effects of thermocline deepening on lake plankton communities." Canadian Journal of Fisheries and Aquatic Sciences 68, no. 2 (2011): 260-276.

[8] Conroy, Ronán M., Michael Elmore-Meegan, Tina Joyce, Kevin G. McGuigan, and Joseph Barnes. "Solar disinfection of drinking water and diarrhoea in Maasai children: a controlled field trial." The Lancet 348, no. 9043 (1996): 1695-1697.

[9] Dufour, A. P. "Escherichia coli: the fecal coliform." In Bacterial indicators/health hazards associated with water. ASTM International, 1977.

[10] Dufour, A. P. "Discussion of indicator thresholds." US EPA, Cincinnati, OH (2001).

[11] Fan, Xiaoyun, Baoshan Cui, Hui Zhao, Zhiming Zhang, and Honggang Zhang. "Assessment of river water quality in Pearl River Delta using multivariate statistical techniques." Procedia environmental sciences 2 (2010): 1220-1234.

[12] Fee, E. J., R. E. Hecky, S. E. M. Kasian, and D. R. Cruikshank. "Effects of lake size, water clarity, and climatic variability on mixing depths in Canadian Shield lakes." Limnology and oceanography 41, no. 5 (1996): 912-920.

[13] Grum, M., R. H. Aalderink, L. Lijklema, and H. Spliid. "The underlying structure of systematic variations in the event mean concentrations of pollutants in urban runoff." Water science and technology 36, no. 8-9 (1997): 135-140.

[14] Hemant, Pathak, Pathak Deepak, and S. N. Limaye. "Studies on the physico-chemical status of two water bodies at Sagar city under anthropogenic influences." Advances in Applied Science Research 3 , no. 1 (2012): 31-44.

[15] Hennig, Christian, Marina Meila, Fionn Murtagh, and Roberto Rocci, eds. Handbook of cluster analysis. CRC Press, 2015.

[16] Horne, Alexander J., and Charles Remington Goldman. Limnology. Vol. 2. New York: McGraw-Hill, 1994.

[17] Iscen, Cansu Filik, Özgür Emiroglu, Semra Ilhan, Naime Arslan, Veysel Yilmaz, and Seyhan Ahiska. "Application of multivariate statistical techniques in the assessment of surface water quality in Uluabat Lake, Turkey." Environmental monitoring and assessment 144, no. 1-3 (2008): 269-276.

[18] Kale, Vijay S. "Consequence of temperature, pH, turbidity and dissolved oxygen water quality parameters." International Advanced Research Journal in Science, Engineering and Technology 3, no. 8 (2016): 186-190.

[19] Kar, P. K., K. R. Pani, S. K. Pattanayak, and S. K. Sahu. "Seasonal variation in physico-chemical and microbiological parameters of 
Mahanadi river water in and around Hirakud, Orissa (India)." The Ecoscan 4, no. 4 (2010): 263-271.

[20] Koklu, Rabia, Bulent Sengorur, and Bayram Topal. "Water quality assessment using multivariate statistical methods - a case study: Melen River System (Turkey)." Water resources management 24, no. 5 (2010): 959-978

[21] Mishra, A. "Assessment of water quality using principal component analysis: a case study of the river Ganges." Journal of Water Chemistry and Technology 32, no. 4 (2010): 227-234.

[22] Mustapha, Adamu, and Ado Abdu. "Application of principal component analysis \& multiple regression models in surface water quality assessment." Journal of environment and earth science 2, no. 2 (2012): 16-23.

[23] Nnaji, C. C., and J. C. Agunwamba. "The environmental impact of crude oil formation water: A multivariate approach." Journal of Water Chemistry and Technology 35, no. 5 (2013): 222-232.

[24] Plimmer, R. J. "Degradation methodology: Chemical and physical effects." In Proceedings of the Workshop on Microbial Degradation of Pollutants in Marine Environments, pp. 423-431. 1978.

[25] Rasolofomanana, Lilia Voahangiarilala. "Characterization of ranomafana lake water quality-antsirabe madagascar." Master's thesis, University of Stavanger, Norway, 2009.

[26] Saleem, Abdul, Mallikarjun N. Dandigi, and K. Vijay Kumar. "Correlation-regression model for physico-chemical quality of groundwater in the South Indian city of Gulbarga." African Journal of Environmental Science and Technology 6, no. 9 (2012): 353-364.

[27] Santos, R. M., A. A. Saggio, T. L. R. Silva, N. F. Negreiros, and O. Rocha. "Short-term thermal stratification and partial overturning events in a warm polymictic reservoir: effects on distribution of phytoplankton community." Brazilian Journal of Biology 75, no. 1 (2015): 19-29.

[28] Sengupta, Pallav. "Potential health impacts of hard water." International journal of preventive medicine 4, no. 8 (2013): 866.

[29] Shedayi, Arshad Ali, Suria Bano, Ming Xu, Sehrish Sadia, and Iqnaa Naseer. "Physicochemical analysis of water quality of Khalti Lake Gupis, Ghizer, Pakistan (a case study)." Science International 28, no. 2 (2016).

[30] Shrestha, Sangam, and F1 Kazama. "Assessment of surface water quality using multivariate statistical techniques: A case study of the Fuji river basin, Japan." Environmental Modelling \& Software 22, no. 4 (2007): 464-475.

[31] Simeonov, V., J. A. Stratis, C. Samara, G. Zachariadis, Dimitra Voutsa, A. Anthemidis, M. Sofoniou, and Th Kouimtzis. "Assessment of the surface water quality in Northern Greece." Water research 37, no. 17 (2003): 4119-4124.

[32] Singh, Kunwar P., Amrita Malik, Dinesh Mohan, and Sarita Sinha. "Multivariate statistical techniques for the evaluation of spatial and temporal variations in water quality of Gomti River (India) - a case study." Water research 38, no. 18 (2004): 3980-3992.

[33] Suthar, Surindra, Jitender Sharma, Mayuri Chabukdhara, and Arvind K. Nema. "Water quality assessment of river Hindon at Ghaziabad, India: impact of industrial and urban wastewater." Environmental monitoring and assessment 165, no. 1-4 (2010): 103-112.

[34] Tajmunnaher, Tajmunnaher, and Muhammad Aktarul Islam Chowdhury. "Correlation Study for Assessment of Water Quality and its Parameters of Kushiyara River, Sylhet, Bangladesh." International Journal of New Technology and Research 3, no. 12 (2017).

[35] Trivedi, Priyanka, Amita Bajpai, and Sukarma Thareja. "Comparative study of seasonal variation in physico-chemical characteristics in drinking water quality of Kanpur, India with reference to 200 MLD filtration plant and ground water." Methods (2009).

[36] United States. Environmental Protection Agency. Office of Water Regulations, Standards. Criteria, and Standards Division. Ambient Aquatic Life Water Quality Criteria for Toxaphene. US Environmental Protection Agency, Office of Water Regulations and Standards, Criteria and Standards Division, 1986.

[37] Varol, Memet, and Bülent Sen. "Assessment of surface water quality using multivariate statistical techniques: a case study of Behrimaz Stream, Turkey." Environmental monitoring and assessment 159, no. 1-4 (2009): 543.

[38] Vervier, Philippe, Adilson Pinheiro, André Fabre, Gilles Pinay, and Eliane Fustec. "Spatial changes in the modalities of $\mathrm{N}$ and $\mathrm{P}$ inputs in a rural river network." Water research 33, no. 1 (1999): 95-104.

[39] World Health Organization. Guidelines for drinking-water quality. World Health Organization, 1993.

[40] Yeung, Iris MH. "Multivariate analysis of the Hong Kong Victoria Harbour water quality data." Environmental monitoring and Assessment 59, no. 3 (1999): 331-342.

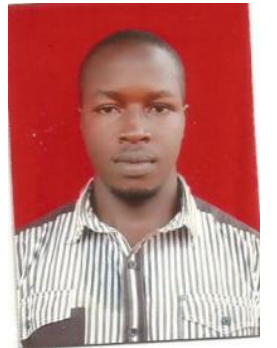

Aneke Nwabueze Peter is currently a Master's student of Water Resources Engineering, Department of Civil Engineering, University of Nigeria, Nsukka. He had his B. Eng. in Civil Engineering, at Michael Okpara University of Agriculture, Umudike, Nigeria. He had an Erasmus mundi scholarship and took part in a Master's mobility programme in Environmental Engineering at the University of Valladolid, Spain.

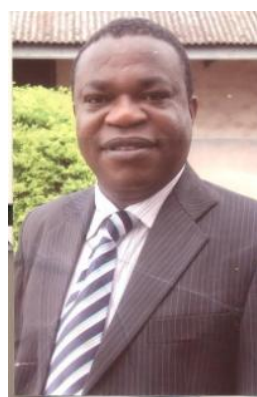

Ademiluyi Joel Ojo is currently Professor of Water Resources and Environmental Engineering at the Department of Civil Engineering at the University of Nigeria, Nsukka. He had a B. Sc. Geology at the University of Ibadan. He got his M. Sc. and $\mathrm{PhD}$ in Water Resources and Environmental Health Engineering from Department of Civil Engineering, University of Nigeria, Nsukka. 